\title{
Kunstiga kiusamise vastu. \\ Kiusuennetustunni eesmärk \\ ja ülesehitus Kadrioru \\ kunstimuuseumi ja Tartu \\ Kunstimuuseumi näitel
}

\section{Hanna-Liis Kont}

\section{Sissejuhatus}

Viimastel aastakümnetel on muuseumid aktiivselt tegelenud oma ühiskondliku rolli ja toimemehhanismide kriitilise analüüsi ning ümbermõtestamisega. Selle tulemusel on asutud pöörama rohkem tähelepanu muuseumi suhtele publikuga ja võimalustele olla lisaks teadmiste vahendajale ka sotsiaalse keskkonna kujundaja. Nende arengute käigus on paljud muuseumid üle maailma hakanud aina aktiivsemalt ja teadlikumalt panustama inimeste sotsiaalsesse heaollu, sealhulgas ka haavatavate või kõrvale jäetud ühiskonnagruppide kaasamisse ja nende vaimsesse ning füüsilisse tervisesse. Silmapaistvalt aktiivseks ja süsteemseks on selles vallas muutunud näiteks Suurbritannia muuseumid eesotsas sealse muuseumiühinguga, mis on välja andnud hea praktika põhimõtteid ja näiteid koondavaid trükiseid, et muuseumide tööd suunata ja toetada (vt nt „Measuring Socially Engaged Practice: A Toolkit for Museums", Museums Association 2018). Samuti on teinud tulemuslikku tööd sealsete ülikoolide teadlased, kes on teostanud mitmesuguseid uurimusi, mis käsitlevad muuseumide potentsiaali eri ühiskonnagruppide sotsiaalsesse heaollu panustamisel (vt nt Dodd ja Jones 2014). Hiljuti on sarnasel teemal korraldatud ka olulisi suurüritusi, mis on toonud kokku arvukalt 
eri valdkondade eksperte, et toetada kultuuriasutuste koostööd sotsiaal- ning tervishoiuvaldkondadega. Nii näiteks oli 2019. aasta märtsis Manchesteris toimunud Maailma Tervishoiu Kongressi üheks peateemaks kunst, tervis ja ühiskondlikud muutused (World Healthcare Congress Europe 2019). Asjaolu, et projekte ja uurimusi, mis seovad muuseumi tegevusi tugevalt tervishoiu- ja sotsiaalvaldkondadega, tehakse üle maailma aasta-aastalt aina rohkem, annab märku, et tegemist on muuseumivaldkonna ühe mastaapse arengusuunaga. Muuseumides nähakse erilist keskkonda, mille toel positiivseid ühiskondlikke muutusi soodustada, näiteks panustada uuel moel kiusuennetusse, rakendades muuseumide rikkalike kogude ja näituste potentsiaali tegevusteks, mida koolikeskkond ei võimalda.

Eestis ei ole veel teadaolevalt muuseumide sotsiaalsele rollile keskenduvaid ja sel moel valdkonnale tervikuna suunda andvaid strateegiaid ega dokumente koostatud. Eesti Muuseumiühingu arengukava aastateks 2018-2022 pöörab peamiselt tähelepanu valdkonnasiseste tegevuste arendamisele, rõhutades ennekõike muuseumiprofessionaalide igakülgset toetamist, mitte aga panustamist laiematesse ühiskondlikesse muutustesse või interdistsiplinaarsesse koostöösse, mis aitaksid muuseumiväljal luua tugevamat sidet teiste valdkondadega (Eesti Muuseumiühingu arengukava 20182022, detsember 2017). Laiahaardelisemate arengusuundade puudumine nimetatud dokumendist on põhjendatav asjaoluga, et tegemist on muuseumitöötajate, mitte muuseumide ühendusega, mille juhatus tegutseb vabatahtlikkuse alusel muu töö kõrvalt, nii et see ei võimalda seada ka väga ambitsioonikaid eesmärke või tegevusplaane. Samas näeb ühingu visioon ette, et soovitakse olla valdkonna arendus- ja kompetentsikeskus, mis annab põhjust arvata, et valdkonna olulised arengusuunad võiksid tulevikus ka nende tegevusplaanides selgemalt kajastuda. Teisalt lasub see vastutus nüüdsest ka Muinsuskaitseametil, mille haldusalasse muuseumide valdkond seoses hiljutise ümberstruktureerimisega kultuuriministeeriumis viidi. Muinsuskaitseameti eesmärkidena on sõnastatud Eesti muuseumivaldkonna arendamine ja muuseumiüleste arenduste eestvedamine (Eesti Muinsuskaitseameti kodulehekülg). Selle konkreetse muudatuse tulemusi on veel vara hinnata. Küll aga võib öelda, et ministeeriumid (ennekõike Haridus-, Kultuuri- ja Sotsiaalministeerium) ei ole muuseumide sotsiaalset potentsiaali seni piisavalt arendanud. Üks võimalus seda teha oleks pakkuda vastava suunitlusega rahastuse võimalusi, mida tehakse näiteks Suurbritannias Arts Councili rahastuspõhimõtete kaudu (Arts Council Englandi kodulehekülg). Kui võrrelda seda Eesti Kultuurkapitaliga, mis rahastab alternatiivsete rahastusallikate vähesuse tõttu muu hulgas ka paljude 
muuseumide projekte, siis on viimane hoidnud seni üsna neutraalset joont ega soodusta oma jaotamispõhimõtetega otseselt sotsiaalse ambitsiooniga projektide esitamist. Ometi on näha, et inimeste heaollu panustavaid projekte tehakse ka siinsetes muuseumides järjest rohkem. Selle suuna üheks näiteks on kiusuennetusega tegelemine.

Senised uuringud on näidanud, et iga viies (mõnes kooliastmes lausa iga neljas) Eesti koolis õppiv laps on kiusamise ohver ning et kiusamisega võib kaasneda ka ärevus ja depressioon. See võib suurel määral mõjutada lapse vaimset tervist ja hakkamasaamist tulevikus, avaldades seeläbi mõju ka ühiskonna üldisele arengule (Iga viies Eesti koolilaps on kiusamise ohver; Arseneault, Bowes ja Shakoor 2009: 717-729). Niisiis on tegemist olulise probleemiga, millega tänaseks tegelevad juba mitmed organisatsioonid. Hetkel kõige aktiivsemaks võib pidada SA Kiusamisvaba Kooli, mis rakendab koolidele suunatud teadus- ja tõenduspõhist kiusamise vähendamise programmi (lühendiga KiVa). KiVa programmi töötasid kümmekond aastat tagasi välja Turu Ülikooli teadlased ning selle on nüüdseks kasutusele võtnud enam kui 20 riiki (KiVa International; KiVa programm - mis, kellele ja milleks?). Eestis tegelevad sama teemaga veel Eesti Õpilasesinduste Liit, MTÜ Lastekaitse Liidu programm „Kiusamisest Vabaks!“, MTÜ Vaikuseminutid, Tartu Ülikooli eetikakeskus ja Tervise Arengu Instituut (Haridus- ja Teadusministeerium 2017). 2018. aastal pöördusid teineteisest sõltumatult nii Kadrioru kui ka Tartu kunstimuuseum Kiusamisvaba Kooli poole sooviga töötada välja kiusuennetusega tegelevad muuseumi haridusprogrammid koolidele. Koostöö tulemusel valmis muuseumitunni „Kunstiga kiusamise vastu” kaks varianti. Tunnid käivitusid 2019. aasta jaanuaris. Kadrioru kunstimuuseumis kaasneb haridusprogramm püsiekspositsiooniga ning Tartus esmalt muuseumi ajutise näitusega „Lugusid kuulumisest. Kaasaegne kunst Rootsist“. Kadrioru kunstimuuseum, mis on üks Eesti Kunstimuuseumi filiaalidest, keskendub vanema väliskunsti tutvustamisele, Tartu Kunstimuuseum aga ennekõike 20.-21. sajandi eesti kunstile (mille kõrval eksponeeritakse pisteliselt ka väliskunsti), kuid Eesti kontekstis on siiski tegemist küllaltki võrreldava suurusega kunstimuuseumidega. Kummagi muuseumi puhul ei ole tegemist esimese korraga, kui projekti keskmes on mõni sotsiaalne valukoht või haavatav ühiskonnagrupp, kelle heaollu püütakse panustada. Näiteks on Tartu Kunstimuuseumis toimunud

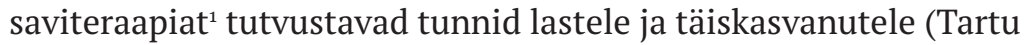
Kunstimuuseumi kodulehekülg 2018) ning Kadrioru kunstimuuseum on

1 Saviteraapia on loovteraapia meetod, mille eesmärgiks on maandada pingeid, aidata saavutada sisemist tasakaalu, leevendada 
astunud samme, et suurendada vaegnägijate juurdepääsu muuseumis pakutavale, luues tähtsamate kunstiteoste kirjeldustõlked (Kadrioru kunstimuuseumi kodulehekülg). Samas võib mõlema muuseumi puhul öelda, et taoline tegevussuund on viimastel aastatel rohkem esile kerkinud ning kiusuennetusega tegelemine on üks osa sellest.

Artikli eesmärk on uurida, miks on nimetatud kunstimuuseumid otsustanud kiusamise ennetamisega tegelema asuda ja kuidas ühendatakse kiusuennetust ning kunsti vahendamist nii haridusprogrammide kui osaliselt ka näituste ülesehituses. Arutluse alla tuleb ka seniste tegevuste jätkusuutlikkuse ja võimalike arengusuundade küsimus. Selleks pakuvad täiendavat konteksti USA muuseumide kiusuennetustunnid. Siinse uurimuse piiridesse ei mahu muuseumitunni mõju põhjalik analüüs (pidades silmas mõju kõigile osapooltele - nii osalenud õpilastele ja õpetajatele kui ka projekti algatanud muuseumidele ja Kiusamisvaba Kooli tegevusele), milleks ei ole veel piisavalt andmeid ja mis eeldaks lisaks museoloogia valdkonna lähtepunktile ka sotsiaal- ja psühholoogiavaldkonna teoreetiliste ja praktiliste uurimismeetodite rakendamist.

\section{Allikad ja meetodid}

Uurimuse peamiseks meetodiks on juhtumiuuring, mille keskmes on haridusprogrammide stsenaariumide ja näitusekeskkondade analüüs. Seda täiendavad haridusprogrammide esmased vaatlusandmed ja tunnis osalenud õpetajate tagasiside ning intervjuud projekti osapooltega. Paari esimese kuu jooksul, mil programm on toimunud, koondasin viie tunni kirjalikud vaatlusandmed ja Tartu Kunstimuuseumi tundides osalenud kuue õpetaja kirjaliku tagasisidevormi vastused. Vaatlusi struktureeris eelnevalt koostatud vaatlusleht, mis oli läbivalt sama ülesehitusega ja kuhu sai märgitud nii tundi puudutav faktiline info (kuupäev, millises muuseumis tund toimus; mitu õpilast osales; mis klass; mis kool; tunni kestus; kes tundi juhendas; milliseid põhimõtteid käsitleti), aga ka vaatluse käigus tekkinud analüütilised tähelepanekud ja märkmed kõnekamatest olukordadest (näited diskussioonist; millised tegevused näisid hästi toimivat ning millised probleemid tunni käigus esile tulid ja miks). Senised vaatlusandmed on olnud suures osas omavahel kooskõlas, tänu millele on neid võimalik kombinatsioonis teiste allikatega esmaste järelduste tegemisel kasutada. Edaspidi on plaanis veel panustada vaatluslehe ja õpetajate tagasisideküsimustiku

traumajärgseid sümptomeid, tugevdada minatunnetust, kasvatada enesekindlust ja hakkamasaamise tunnet. 
metoodilisse ülesehitusse, tuginedes nii praeguseks kogunenud kasutuskogemusele kui ka täiendavale erialasele kirjandusele. Õpetajate esmane tagasisideküsimustik koosnes kuuest küsimusest: 1. Kas Teie kool on liitunud KiVa programmiga?; 2. Kui efektiivselt toetas muuseumitund kiusuennetuse teadmiste edasiandmist või kinnistamist?; 3. Millised tunni tegevused toimisid Teie hinnangul kõige paremini ja miks? Mida soovitaksite tunni puhul teisiti teha?; 4. Mida arvate muuseumi keskkonnas kiusuennetusega tegelemisest võrreldes koolis sama teema õpetamisega?; 5. Kas soovitaksite seda tundi oma kolleegidele?; 6. Täiendavad kommentaarid. Link küsimustikule edastati Tartu Kunstimuuseumi külastanud õpetajatele e-posti teel mõned päevad pärast tunni toimumist. Kadrioru kunstimuuseumi tunnis osalenud õpetajate seas pole piiratud ajaressursi tõttu veel olnud võimalik küsitlust teha.

Täiendavate andmete kogumiseks on tehtud intervjuud nelja seotud osapoolega, nende seas kolme tunnijuhiga: Eliis Vaino (tunni „Kunstiga kiusamise vastu“ koostaja, tunnid nii Kadrioru kui ka Tartu Kunstimuuseumis), Kristel Sibul (Tartu Kunstimuuseum) ja Loore Sundja (Kadrioru kunstimuuseum). Valituks osutusid need tunnijuhid, kes on seni enim tunde andnud või nende koostamisega tihedalt seotud olnud. Samuti on intervjueeritavate seas Triin Toomesaar, kes on SA Kiusamisvaba Kooli tegevjuht ja olnud programmi koostamisel nõuandvas rollis. Kolm intervjuud toimus näost näkku ja neist on olemas nii lindistused kui ka üleskirjutused, Loore Sundjaga toimus ainsana meiliintervjuu. Samuti on olulisteks allikateks rahvusvahelisi projekte kajastavad artiklid ja uurimused eesotsas Ashley Scotto magistritööga (2014), mis vaatleb USA muuseumide näitel kiusuennetuse koostöövõimalusi muuseumide ja koolide vahel.

Lisaks uurija rollile, mille olen võtnud siinset artiklit ette valmistades ja kirjutades, olen teemaga seotud ka kuraatori ja tunnijuhina. Olen Tartu Kunstimuuseumi näituse „Lugusid kuulumisest. Kaasaegne kunst Rootsist“ kuraator koos Joanna Hoffmanniga ning algatasin 2018. aastal Tartu Kunstimuuseumi dialoogi Kiusamisvaba Kooliga. Samuti olen tunnijuhina viinud samal näitusel läbi programmi „Kunstiga kiusamise vastu“. Seda arvesse võttes pean oluliseks kirjeldatud protsesside kaardistamist ja analüüsi, pidades seejuures silmas oma mitmetist seotust uuritava materjaliga.

\section{Miks tegeleda muuseumides kiusuennetusega?}

Juba mitukümmend aastat on ühe muuseumide peamise arengusuunana esile toodud püüdlusi muuta need institutsioonid oma kogukondadele 
relevantsemaks, seades inimeste vajadused muuseumi tegevuste planeerimisel kesksemale kohale. See põhimõte on ka oluline osa uue museoloogia ja hilisema postkriitilise museoloogia teooriate tõekspidamistest, mis toetavad rõhuasetuse liikumist institutsiooni traditsioonilistelt töömehhanismidelt ja autoriteetsuse kuvandilt muuseumi ühiskondlikele eesmärkidele ja panusele (vt nt van Mensch 2004; Marstine 2006; Dewdney 2012). Selle üldisema suunitluse kontekstis on aina rohkem muuseume hakanud teadlikumalt investeerima inimeste heaolu suurendavatesse tegevustesse, sealhulgas näiteks sotsiaalse sidususe ja vaimse tervisega seotud algatustesse. Ühelt poolt on see arengusuund seotud taotlusega lõhkuda ühiskondlikke hierarhiaid, mille tekitamise eest on muuseume kui (pikka aega) elitaarseid institutsioone kritiseeritud. Teisalt on selle esile kutsunud ka museoloogia kui teadusvaldkonna hiljutised spetsiifilisemad arengud, kus on jõutud aina kindlamatele järeldustele, et muuseumidel on eriline potentsiaal oma kogude ja keskkonna kaudu ka inimeste tervisesse panustada. Viimast saavutatakse näiteks mõjusate sotsiaalsete kogemuste pakkumise ja positiivsete emotsioonide tekitamise abil, mis on omakorda seotud sotsiaalse sidususe suurendamise ja vaimse (aga ka füüsilise) tervisega. Muuseumiprojektide mõju hindamiseks on kasutusele võetud näiteks Londoni Ülikooli Kolledži (UCL) välja töötatud muuseumi heaollu panustamist hindav abivahend ehk UCL Museum Wellbeing Measures Toolkit (Thomson ja Chatterjee 2013) ja ka teisi analoogseid töövahendeid, mis sisaldavad valdavalt mitmesuguseid küsimustikke, mille abil püütakse võimalikult täpselt välja selgitada, kuidas muuseumikülastajad ennast külastuste käigus või järel tundsid ning mida külastustest arvasid. Laiemas plaanis on mainitud valdkondlikud arengud osaks globaliseeruva maailma mastaapsematest ühiskondlikest protsessidest, mille käigus on hakatud rohkem tähelepanu pöörama sellistele teemadele nagu sotsiaalne ebavõrdsus, kultuuriline erinevus, diskrimineerimine ja inimeste kõrge stressitase seoses kiire elutempo ja info üleküllusega - probleemid, millele otsitakse lahendusi paljudes valdkondades, teiste seas ka muuseumides.

Kirjeldatud arengute käigus on aga ilmnenud, et sihtgruppe, kellele muuseumid võiksid tähelepanu pöörata ja kellega koostööd teha, on väga palju. Teatud muuseumide puhul on haavatavate ühiskonnagruppide esindamine lähtuvalt nende kogude spetsiifikast olemuslikult kesksel kohal. Sotsiaalse suunitlusega projektide varasemast hoogsamat esilekerkimist on viimasel kümnendil märgata aga kõikvõimalike teemade ja valdkondadega tegelevates muuseumides, teiste seas kunstimuuseumides. Näiteks on hakatud aktiivselt panustama dementsuse diagnoosiga inimeste programmidesse, 
mis käivitusid MoMAs juba aastal 2007 (Meet Me at MoMA, MoMA kodulehekülg). Aastal 2018 toimus sellele sihtgrupile suunatud pilootprogramm „Taaskohtumised“ ka Kumu kunstimuuseumis (Kumu kunstimuuseum 2018). Samuti on tehtud mitmetes kunstimuuseumides koostööd pagulastega (Multaqa, Cities of Migration 2017), kodututega (Sing me to Sleep; Petkute ja Gudonytė jt 2016) ja paljude teiste haavatavate ühiskonnagruppidega. Niisiis tekib küsimus, miks otsustas kaks Eesti kunstimuuseumi - Kadrioru ja Tartu Kunstimuuseum panustada üsna samaaegselt just kiusuennetusse?

Viimase paarikümne aasta jooksul on mõlema kunstimuuseumi haridustöö oluliseks osaks saanud järjepidev kooligruppidega töötamine ja koostöö õpetajatega. Kooliõpilased moodustavad suure ja olulise ühiskonnagrupi ning õpetajad tänuväärse sidusrühma, kellega koostöö tegemine võimaldab muuseumil hõlpsamini kujundada järeltulevate põlvkondade suhtumist ja teadmisi kunstist. Seega on nad kohalikele kunstimuuseumidele üks prioriteetsemaid sihtgruppe ja saavad rohkem tähelepanu kui mitmed teised potentsiaalsed sihtgrupid, näiteks pagulased, keda oli Eestis 2018. aasta seisuga alla 500 (Eesti Pagulasabi 2018). Kuna kiusuennetus on muutunud viimastel aastatel ka Kiusamisvaba Kooli ja teiste mainitud organisatsioonide tegevuse mõjul Eesti koolides palju teadvustatumaks tegevussuunaks, siis on see teema jõudnud ka muuseumideni. Kiusuennetuse vallas koostöö tegemise algatus tuli muuseumitöötajatelt, kes tajuvad oma erialase lähtepunkti tõttu, et muuseumides peitub potentsiaal sellistes küsimustes kaasa aidata. Samuti on mõned tunnijuhid, kaasa arvatud siinkirjutaja, kogenud muuseumitundides teatavaid kiusamisele viitavaid olukordi, mida on olnud keeruline ilma vastavate teadmisteta lahendama asuda. Muuseumitöötajatele korraldatud koolituse käigus rõhutas Triin Toomesaar KiVa raames teostatud uuringutele toetudes samuti, et kiusamise ennetamiseks ja peatamiseks jääb intuitiivsest tegevusest väheks ja see võib halvemal juhul hoopis kahju tekitada (Koolituse märkmed, VM 2019, Tallinn). Üks küllaltki levinud olukord, mis muuseumitunnis ilmsiks tuleb, näib olevat mõne õpilase järjekindel tõrjumine grupitööd eeldava tegevuse käigus. See viitab pigem klassikollektiivis väljakujunenud mustrile kui juhuslikule tülile või arusaamatusele (Vaino 2019; Sundja 2019; „,Kunstiga kiusamise vastu“ tunni vaatluste andmed, VM 2019, Tartu ja Tallinn). Sellised juhtumid näitavad, et muuseumitöötajatel ei ole mõistlik kiusuennetuse vallas passiivseks jääda, vaid tunnetatakse vajadust täiendavate teadmiste järele, et olukordi teadlikumalt hinnata ja vajadusel pädevalt sekkuda. Kiusuennetusprogrammi käivitamise eel said mõlema muuseumi tunnijuhid end selles vallas ka täiendada, osaledes 
Toomesaare lühikoolitusel, kus käsitleti lähemalt kiusamise olemust ja toimemehhanisme ning seda, kuidas kõige efektiivsemalt kiusamist ennetada ja kiusamise olukorda sekkuda. Seejuures tutvustati ka KiVa programmi sisu ja sellel põhinevat muuseumitundi „Kunstiga kiusamise vastu“. Saadud teadmised on muuseumitöötajatele kasulikud nii kiusuennetustunni kui ka kõigi teiste muuseumitundide puhul, kus on vaja töötada kooliealiste lastega. Niisiis oleks taoline koolitus abiks ka neile tunnijuhtidele, kes otseselt kiusuennetustunde ei anna, aga töötavad muude programmide käigus muuseumides laste ja noortega.

Lisaks kirjeldatule ja programmi kesksele eesmärgile ehk soovile ühiskonnas kiusamist vähendada on veel mitmeid põhjusi, miks muuseumid võiksid olla motiveeritud kiusuennetusega tegelema. USA muuseumide kiusuennetuse programme uurivas magistritöös toob Ashley Scotto muuseumide kasutegurina esile kogukonnas positiivse rolli omandamise ja suurema koolide osaluse, aga ka potentsiaalse lisarahastuse kaasamise (lähtuvalt USA fondidest, mis taolisi projekte Scotto sõnul meelsasti toetavad) ja võimaluse muuseumi missiooni täita (Scotto 2014: 50-55). Võrreldes neid motivaatoreid kohalike algatustega, ilmnevad teatavad erisused. Ei Kadrioru ega ka Tartu Kunstimuuseumi puhul ei lähtunud koostööidee konkreetse muuseumi missioonisõnastusest või kehtestatud strateegia elluviimise soovist ega kasvanud välja ka terendavatest rahastusvõimalustest. Pigem vastupidi - ideed tekkisid üksikute töötajate peas strateegilistest arendustegevustest ja taotlusvoorudest otseselt sõltumata ning ka tunni väljatöötamine toimus valdavalt algatajate isikliku huvi ja motivatsiooni toel ning väikese eelarvega (Vaino 2019). Selleks et tagada programmi jätkusuutlikkus pikemas perspektiivis ja vähendada selle sõltumist üksikute inimeste initsiatiivist, peaks see olema osa muuseumi laiemast strateegiast kogukondadega suhtlemisel. Ka selliseid projekte toetavate rahastusvõimaluste lisandumine Eesti kultuurimaastikule aitaks nende algatuste jätkusuutlikkusele kaasa. Scotto mainitud motivaatoritest on kõige asjakohasemad antud juhtumite puhul koolide suurema osaluse saavutamine ja kogukonnas positiivse rolli omandamise soov. Viimase puhul on toeks ka aina suurem hulk uurimusi museoloogia valdkonnas, milles tuuakse rohkelt näiteid ja tõendusmaterjali, et muuseumid suudavad inimeste tervisesse ja heaollu panustada ning et taoline tegevus tugevdab muuseumide sidet kogukondadega (vaata nt Dodd ja Jones 2014). Seejuures pole vähem tähtis tõsiasi, et Eesti muuseumimaastikul ollakse tänu erialaste haridusvõimaluste mitmekesistumisele ja rahvusvahelistes võrgustikes osalemisele aina paremini selliste arengutega kursis ning rakendatakse 
neid kohalikele vajadustele vastavalt ka praktikas. ${ }^{2}$ Nii võimaldab programm ka kohaliku muuseumihariduse uuendamisse panustada, mis on samuti üks täiendav motivaator.

Ideest reaalse muuseumitunnini jõudmisel oli võtmetähtsusega uutele katsetustele avatud koostööpartneri olemasolu. Kiusamisvaba Kooli toel toimus tunni väljatöötamine, tunnijuhtide koolitamine ja osaliselt ka info levitamine KiVa-ga liitunud koolidele. Tekkinud koostööd toetab asjaolu, et kõigil osapooltel on võimalik sellest oma eesmärkide valguses midagi võita. Kiusamisvaba Kooli vaatepunkti tutvustades toob Toomesaar välja, et koostööettepanek otsustati vastu võtta, kuna muuseumid olid valmis ise sisulisse töösse panustama ja tunni välja töötama ning valminud muuseumitunni abil saab levitada infot KiVa kohta ka neile koolidele, kes pole veel programmiga liitunud. Samuti pakub tund liitunud koolidele täiendavat tegevust, mille käigus kiusuennetuse põhimõtteid kinnistada (Toomesaar 2019). Viimasest on abi ka üldhariduskoolidele, kellel oleks väga keeruline ilma muuseumide panuse ja infrastruktuurita taolisi programme koostada. Mitmetes muuseumiharidust analüüsivates uurimustes on esile toodud, et muuseum on toetav keskkond keeruliste teemade käsitlemiseks, kuna tegemist on kooliga võrreldes neutraalsema ja paindlikuma ruumiga, kus saab eksponaatide tõlgendamise kaudu nüüdisaja probleemidele uusi vaatenurki pakkuda (vaata nt Dickstein Thompson 2010: 51). Ka õpetajate esmane tagasiside näitab, et hinnatakse võimalust tegeleda teemaga väljaspool kooli, kuna see pakub ühelt poolt vaheldust ja uutmoodi lähenemist, aga näitab ka seda, et mujal kehtivad omavahelise suhtluse puhul samad reeglid, mida koolis õpetatakse (õpetajate tagasisideküsitluse vastused 2019).

Kuigi muuseumide kiusuennetusega tegelemise idee on seni kõigilt osapooltelt valdavalt positiivset vastukaja saanud, leidub ka argumente, miks algatusse teatava ettevaatlikkusega suhtuda. Juba eespool mainitud tunnijuhtide vähene kogemus ja pädevus kiusujuhtumite lahendamisel tähendab, et väljatöötatud programm paneb muuseumitöötajad selles vallas senisest intensiivsemalt proovile. Sibul tõi välja, et tema esimesed emotsioonid seoses plaanitava programmiga olid seotud mõningase teadmatuse ja kartusega ning et teadlaste koondatud teadmised ja välja töötatud lähenemised on vaja osata just kohaliku kogukonna vajadustega kokku viia, mitte lihtsalt kriitikavabalt üle võtta. Eestis on kohalikest vajadustest lähtuvalt asunud vaimse tervise vallas panustama ka näiteks Eesti Rahva Muuseum, kes algatas koostöö Tartu Ülikooli psühhiaatriakliinikuga, pakkudes sealsetele patsientidele regulaarset programmi, millesse on alates 2019. aastast kaasatud mitmed teisedki Tartu muuseumid. 
vastutus oli tavapärasest muuseumitunnist suurem. Siiski nentis ta, et tunnid ei ole nii keeruliseks osutunud, kui ta algselt pelgas (Sibul 2019). Sellegipoolest peab arvestama, et tunnijuhtidel on vaja oma teadmisi selles vallas jooksvalt täiendada, seda enam, et senised koolitused on olnud üsna põgusad. Algusest peale on teadvustatud ka tõsiasja, et muuseumitunni praeguse formaadi juures, kus iga klass tuleb muuseumisse kiusuennetusega tegelema vaid korra, ei ole saavutatav mõju väga suur ja efektiivsuse tõstmiseks oleks vaja välja töötada jätkusuutlikum lahendus. Samuti viitab Toomesaar vajadusele arvestada võimalusega, et muuseum ei pruugi kiusuennetusega tegelemisel osutuda alati kõige kasulikumaks partneriks või paigaks, näiteks võib parasjagu klassis kõne all olev aspekt olla eriti tundlik ning sobilikum arutamiseks kooli tuttavas keskkonnas ja siseringis (Toomesaar 2019). Seega võiks käimasolevat programmi näha pilootprojektina, mille tugevus seisneb ennekõike pikemaajalise uurimistegevuse ja arengusuuna käivitamises, mis võimaldab esmaseid ideid katsetada ja saadud kogemuse pinnalt järgmised tegevused ning võimalikud arengusuunad paika panna. Toetudes nii senisele kogemusele kui ka museoloogia valdkonna rahvusvahelistele uurimustele ja arvukate kogukonnaprojektide edukusele, on põhjust arvata, et ka kiusuennetuse vallas on võimalik välja arendada muuseumide ja koolide süvendatumat ja jätkusuutlikumat koostööd võimaldavad formaadid. ${ }^{3}$ Vajadus ja avatus selleks, et teineteist kiusuennetuse vallas toetada, on nii koolide kui ka mõlema muuseumi poolt tajutav, eriti arvestades tõsiasja, et tegemist ei ole probleemiga, mida saaks kiiresti lahendada, vaid järjepidevust eeldava valdkonnaga, kuhu tuleb pidevalt ressursse suunata. Niisiis näib jätkusuutlike partnersuhete loomine olevat üks viis, kuidas koormust leevendada ja vastutust jagada.

\section{Kuidas ühendada kiusuennetust kunsti vahendamisega?}

Sellist lähenemist, kus kiusuennetuseks vajalikke hoiakuid püütakse muuseumiobjektide abil sihipäraselt edasi anda, on enne siinse programmi väljatöötamist kasutatud ka mujal maailmas. Scotto toob oma uurimistöös välja mitmeid USA muuseume, mille programmide

3 Tartu kannab aastal 2024 Euroopa kultuuripealinna tiitlit. Kultuuripealinna programmi raames olen koostöös Eliis Vainoga algatanud rahvusvahelise projekti „Luues lähedust. Kiusuennetus kunstimuuseumis“, mille eesmärk on pikema aja jooksul mitmeetapilise uurimistöö käigus kirjeldatud jätkusuutlikumaid formaate välja töötada ning valdkonnaga seotud eksperte ja nende ideid kokku tuua. 
eesmärk on aidata õpilastel märgata võimalikke lahendusi tänastele probleemidele ajalooliste sündmuste või objektide tutvustamise näitel, suurendamaks õpilaste empaatilisust ja sallivust (2014: 39). Üheks kõnekaks näiteks on Arkansases asuv Crystal Bridges Museum of American Art, mille koolidele suunatud programmidest tehti 2013. aastal mahukas uurimus (osales 10912 õpilast ja 489 õpetajat 123 koolist) (Crystal Bridges Museum of American Art 2013). Uuringus küsitleti paralleelselt muuseumi külastanud õpilasi ja kontrollgrupi õpilasi, kes ei olnud muuseumiprogrammis osalenud. Poolepäevastes muuseumikülastustes ühendati tuuride ja arutelude käigus kunstiteoste tutvustamine Ameerika Ühendriikide ajaloo sündmuste käsitlemisega. Küsitlus toimus keskmiselt kolm nädalat pärast külastust ning selle tulemused näitasid, et külastuse mõjul suurenes õpilaste suutlikkus kunstiteoseid iseseisvalt analüüsida ja nende vastustes väljendus ka suurenenud sallivus ja empaatia nii ajaloosündmuste suhtes kui ka tänapäeva kontekstis. Väärtushinnanguid puudutav muutus oli kontrollgrupiga võrreldes protsentuaalselt küll pigem väike (erinevate küsimuste puhul 4-7\%, maapiirkonna ja vaesemate piirkondade koolide õpilaste puhul olid erinevused suuremad), aga ühe muuseumikülastuse kohta siiski piisavalt kõnekas, et näidata taoliste programmide potentsiaali panustada laste ja noorte väärtushinnangute kujundamisse (Greene, Kisida ja Bowen 2014). See näide toetab ka siinse kiusuennetustunni koostamisel lähtepunktiks olnud arvamust, et kunsti tundmist ja sotsiaalseid oskusi ning hoiakuid on võimalik samaaegselt õpetada ja kujundada, kuid kinnitab samas tõsiasja, et ühest külastusest ei piisa mastaapsemate muutuste esilekutsumiseks. Viimane aspekt on muuseumidele küll teada, kuid koolide piiratud ajaline ressurss muudab mahukamate programmide elluviimise keeruliseks, millest tulenevalt on paljude Eesti muuseumide haridusprogrammid siiski üles ehitatud ühekordsetele külastustele. Samas on korraldatud ka korduvatest külastustest koosnevaid programme, Kumus näiteks „Täpi“ ja „Lugusid kunstis" (Kumu kunstimuuseum 2019), kuid taoliste formaatide sissetöötamine eeldab üldjuhul tihedamat ja pikaajalisemat suhtlust koolidega, et luua selline sisu, mis kataks mitmeid kooliprogrammi teemasid, motiveerimaks õpetajaid neisse rohkem oma tunni aega panustama.

Vastates küsimusele, kuidas on kiusuennetusega seotud tegevused ühendatud muuseumide tavapäraste põhitegevustega ehk antud juhul kunsti vahendamise ja populariseerimisega, on vaja pöörata suuremat tähelepanu programmi ülesehitusele ja toimimisloogikale seda nii ideelisel tasandil kui ka praktikas. Eliis Vaino, kes tunni koostas, tugines koolidele mõeldud KiVa programmi õppematerjalidele, võttes aluseks esimeses moodulis sisalduvad põhimõtted, mis on mõeldud 
ennekõike kuue- kuni seitsmeaastastele lastele ehk esimesele klassile. Kuna KiVa eesmärk ei ole ainult kiusamise peatamine, vaid ka selle ennetamine, siis alustatakse KiVa tegevustega juba esimeses klassis, enne kui negatiivsed suhtlusmustrid jõuavad uues grupiolukorras välja kujuneda. Tunnis kasutatavad põhimõtted on sõnastatud järgmiselt: kedagi ei jäeta välja; hoolimine on tugevus; erinevus on rikkus; meie ei kiusa; meie ei ühine kiusajatega; aitame ja julgustame kiusatud lapsi; räägime kiusamisest mõnele täiskasvanule; julgen kiusamisele vastu astuda (Salmivalli, Poskiparta, Tikka ja Pöyhönen 2013). Kiusuennetust toetavatele põhimõtetele otsis Vaino mõlema muuseumi näitustelt juurde teosed, mille kaudu oleks võimalik neid põhimõtteid tunni käigus õpilastele eakohasel moel ja mitmesuguste tegevuste abil tutvustada või üle korrata (Vaino 2019). Muuseumitunni puhul on sihtgrupina määratletud kogu põhikooli I aste (esimesed kuni kolmandad klassid, kuid mõnel korral on tunnis osalenud ka neljandad klassid), kuna tundi saab kasutada ka kordamisena ning samuti saavad selles osaleda nende koolide grupid, kes pole KiVa-ga liitunud ja neid teemasid veel põhjalikult läbinud.

Kuigi muuseumitunnist „Kunstiga kiusamise vastu“ valmis kaks versiooni, vastavalt Kadrioru ja Tartu Kunstimuuseumile, mida hiljem lähemalt võrdlen, tasub esmalt peatuda tunni struktuuril, mis on mõlemas muuseumis sama. Programm kestab 90 minutit ja koosneb tegevustest, mida saab üldistades jagada kolmeks: grupi ühist diskussiooni võimaldavad tegevused, koostöömängud ja käeline tegevus. Keskne roll on tunnis aruteludel, mis lähtuvad valdavalt kunstiteostest ja mida toetavad kokkuvõtvad põhimõtte- või tunnusekaardid (A3 formaadis värvilised kaardid, millel on vastavad põhimõtted trükitähtedes kirjas), mis aitavad selge ja silmatorkava visuaali abil vestluse käigus esile kerkinud põhimõtteid paremini nähtavale tuua ja meelde jätta. Enne näitusesaali minekut algab tund aruteluga, kus õpilaste pakkumiste kaudu ja tunnusekaartide abil defineeritakse kiusamise mõiste, rõhutades järgmisi aspekte: kiusamine on tahtlik ehk seda tehakse meelega, tehakse kahju või haiget, kiusataval on end raske kaitsta. Seeläbi tuuakse esile ka kiusamise ja ühekordse tüli või kogemata teisele haiget tegemise erinevused. Vaino on nentinud, et sellise tõsise teemaga alustamine on pisut raske ning et vältida liiga nukra tuju tekkimist, tuleb see muuta jõustavaks ehk anda lastele märku, et igaüks saab kiusamise ennetamiseks ja vähendamiseks midagi ära teha (Vaino 2019). Seepärast antakse õpilastele roll ja nad saavad ülejäänud tunniks kehastuda kiusamise lõpetamise ekspertideks, andes kunstiteoste tegelastele nõu, kuidas tasuks vastavates olukordades toimida. Sarnases programmis on rollimängu toetava pedagoogilise meetodina kasutanud näiteks Simon Wiesenthali keskuse juurde 
kuuluv Museum of Tolerance Los Angeleses, kus õpilased kehastuvad kiusuennetustunnis uurijateks või avastajateks (explorers) (Museum of Tolerance).

Pärast kiusamise mõiste defineerimist peatutakse põhjalikumalt nelja kunstiteose juures, mida tutvustatakse sotsiaalsete olukordade või lugude kirjeldamise kaudu, sidudes neid ka koolis või kodus ette tulevate situatsioonidega (õpilaste varasemate kogemustega). Lapsed jagavad seejärel kogu grupiga, kuidas nemad vastavates olukordades käituksid või on käitunud. Iga teose juures jõutakse arutelus välja ühe kuni kahe tunni ülesehituses määratletud põhimõtteni, mille abil kiusamist ennetada või peatada. Kadrioru kunstimuuseumi tunnis tutvuvad lapsed näiteks 17. sajandist pärineva Lambert de Hondt I maaliga „Teekond Noa laeva“, mille kaudu räägitakse põhimõttest „Erinevus on rikkus“. Tartu Kunstimuuseumis tutvutakse teiste seas kaasaegse kunstniku Meriç Algüni kohaspetsiifilise installatsiooniga „Laenutamata raamatute kogu“ (foto 1), mida tunnijuhid kasutavad, et jõuda arutelus põhimõtteni „Kedagi ei jäeta välja“. Niisiis on kunsti tutvustamine oluline osa tunnist, kuid fookus on nihkunud väärtuste ja hoiakute kujundamisele. USA muuseumihariduse spetsialistid Julie Johnson ja Janet Rassweiler on muuseumide, koolide ja kogukondade ühiseid õppetegevusi analüüsides samuti tõdenud, et tihedam koostöö eeldab muuseumitöötajate rolli ja oskuste muutumist ning asetab väärtushinnangute õpetamise kesksemale kohale kui konkreetse valdkonna teadmiste edasiandmise (Johnson ja Rassweiler 2010: 71). Nagu eelnevast ilmneb, ei tähenda see siiski, et kunsti vahendamine kõrvale jääb. Pigem luuakse kunsti ja igapäevaelu vahele selgem seos, demonstreerides kunsti praktilist potentsiaali maailma mõtestamisel. Seda on esile toonud ka õpetajad, kellele on meeldinud, et tund pakub lastele võimaluse minna kunstniku või teose olukorda ja näha kiusamist kunstniku vaatepunktist (õpetajate tagasisideküsitluse vastused 2019).

Lisaks aruteludele sisaldab muuseumitund mitmesuguseid laste koostööd ja grupitööd eeldavaid mängulisemaid tegevusi. Nende

Foto 1

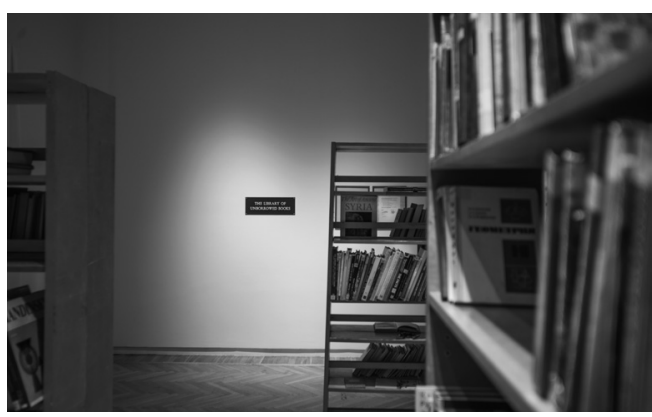


ülesanne on muuta tund aktiivsemaks ja vaheldusrikkamaks ning anda võimalus arutelu käigus leitud põhimõtteid praktikas läbi proovida. Näiteks peavad õpilased seoses põhimõttega „Kedagi ei jäeta välja“ leidma juhuslikesse gruppidesse sattumise järel oma grupi liikmeid ühendava sarnasuse. Selle kaudu tuuakse esile, et kõigi inimestega on soovi korral võimalik leida ühisosa, mille abil tutvust teha ja neid kaasata. Gruppideks jagunemiseks antakse igale õpilasele juhusliku pildiga kaart. Sama pildi saanud õpilased peavad üksteist üles leidma ja grupid moodustama. Kui keegi jääb seejuures üksi (mis võib selle süsteemi puhul juhtuda ja on taotluslikult sisse arvestatud), siis rõhutab tunnijuht, et nüüd avaneb võimalus järgida äsja õpitud reeglit „Kedagi ei jäeta välja“. Seni on see valdavalt ka toiminud ning lapsed on suutnud ise tekkinud probleemi lahendada, kutsudes üksi jäänud õpilased enda grupiga liituma („Kunstiga kiusamise vastu“ tunni vaatluste andmed, VM 2019, Tartu). Samuti mängitakse „Hea tuju kingituse“ mängu, mille käigus tehakse või öeldakse paarilisele midagi sellist, mis võiks tema tuju paremaks teha. Viimast on toonud tunni ühe positiivsema osana esile nii Vaino kui ka Kadrioru kunstimuuseumi haridusprogrammide kuraator Loore Sundja, kes leiavad, et see loob alati väga positiivse õhkkonna ja hea tunde, mis on tunni teemat arvestades oluline. Mängud ja grupitööd on tunnijuhtidele ka raskeid olukordi tekitanud, kuna suurema klassi puhul (üle 20 õpilase) jääb ühest tunnijuhist sageli väheks, et kõigi gruppide tegevust samaaegselt jälgida ja toetada („Kunstiga kiusamise vastu“ tunni vaatluste andmed, VM 2019, Tartu ja Tallinn). Selles olukorras muutub väga oluliseks kaasas oleva õpetaja või õpetajate roll, kes saavad aidata ja teavad tunnijuhist üldjuhul paremini, millised lapsed või grupid võivad sellises olukorras vajada teistest enam tuge. Koostöömängude käigus ilmneb kõige sagedamini ka see, kui mõnda õpilast klassis tõrjutakse ja ei taheta kaasata. Niisiis on väga oluline, et muuseumitöötajad ja õpetajad tunni eel omavahel suhtleksid, et leppida kokku vastastikustes ootustes ja vahetada infot klassi vajaduste kohta. Muidu võib juhtuda, et õpetaja jääb muuseumitunni ajal passiivsemaks, kui tunnijuht sooviks või vajaks, või ei oska muuseumitöötaja tundi klassi vajadustele kohandada.

Tunni lõpetab käeline tegevus, mille käigus jagunevad lapsed taas gruppidesse ja iga grupp joonistab ühe leitud põhimõtte juurde illustreeriva pildi. Kõik pildid koos põhimõtteid väljendavate tekstidega kleebitakse seejärel plakatile, millest kujuneb klassi leping ja mille õpilased saavad pidulikult allkirjastada (foto 2, 3) ning kooli kaasa võtta. Joonistamine võimaldab lisaks loomingulisele tegevusele põhimõtete sisu veel kord läbi mõelda ja visualiseerimise kaudu kinnistada. Lepingu koostamine on aga oluline, et rõhutada ühise kokkuleppe sõlmimist ja lubadust neid põhimõtteid järgida. Vajadusel 
saavad õpetajad sellele ka hiljem viidata, kui koolis neist kinni ei peeta. Scotto uurimistöösse koondatud USA muuseumiprogrammide seas leidub analoogne näide. Baltimore'is asuv The Walters Art Museum on kasutanud oma keskaja kunsti kogusid, et tutvustada õpilastele kuldset reeglit, mille kohaselt tuleb kõiki võrdselt ja ausalt kohelda, ning keskaja aukoodeksit. Seejärel loovad õpilased tunnis oma aukoodeksi. Sarnaselt kohalikule programmile kombineeriti ka seal käitumisreeglite õppimine loova tegevuse ning grupitööga (Scotto 2014: 41-42). Nii on õpilastega taoliste, tavapäraselt pigem täiskasvanute maailma kuuluvate ametlike kokkulepete läbimängimist ehk nii-öelda tähtsate dokumentide koostamist peetud mitmel pool efektiivseks viisiks, kuidas muuseumikogude ja ühiskondlike käitumismudelite tutvustamist muuseumitunnis siduda ning õpilastele erilist ja meeldejäävat kogemust pakkuda. Kui õpilased on valdavalt põhimõtetega nõustunud ja allkirjastamisse innukalt suhtunud, siis

Foto 2, 3
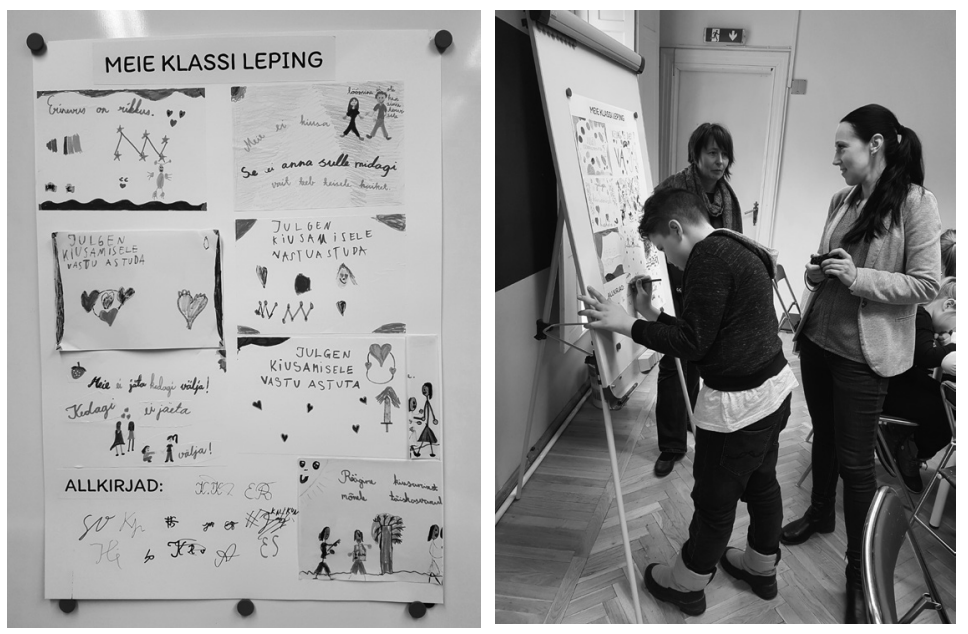

Vaino on sattunud ka olukorda, kus mõni õpilane ei ole kõigi punktidega nõus või ei ole valmis lepingule alla kirjutama. See tähendab, et tekib vajadus võimalusel individuaalselt täiendavalt teema üle arutleda või ajapuudusel leppida sellega, et kõiki ei õnnestugi tunni käigus veenda (Vaino 2019). Seega on oluline, et klass ei osaleks ainult ühes kiusuennetustunnis ja õpetajad ei jääks selle mõjule liigselt lootma, vaid tegeleks teemaga järjepidevalt edasi. Seda võimaldab KiVa programmi laiem raamistik. Samuti tasuks mõelda, kas ja millisel viisil võiks konkreetse muuseumitunni osaks olla klassis tehtav jätkutegevus, mis lepitakse õpetajaga eelnevalt kokku ja aitab veelgi muuseumis ja koolis toimuvat õppimist seostada ning teadmisi kinnistada. 


\section{Kiusuennetustunni sidumine Kadrioru kunstimuuseumi ja Tartu Kunstimuuseumi näitustega}

Nagu mainitud, on muuseumitund „Kunstiga kiusamise vastu“ kohandatud kahele näitusele - Kadrioru kunstimuuseumis toimus tund püsiekspositsioonis ning Tartu Kunstimuuseumis esialgu ajutisel näitusel „Lugusid kuulumisest. Kaasaegne kunst Rootsist“ (18.01.-5.05.2019). Erinevad näitusekeskkonnad toovad endaga kaasa ka mitmeid erisusi tunni sisus ja praktilises teostuses. Kõige suurem erinevus tulenebki sellest, et arutelud lähtuvad mitmest kunstiteosest. Kadrioru kunstimuuseumi puhul valiti sobivad teosed püsiekspositsioonist, kuna see võimaldab tunnil programmis püsida pikema aja jooksul ilma suuremate muudatusteta. Sellegipoolest nendib Vaino, et ka püsiekspositsioon ei ole osutunud nii püsivaks, kui võiks arvata, ja vahepealse aja jooksul on tulnud tunnis muudatusi teha, kuna „Suurvürstinna Jekaterina Aleksejevna ratsaportree” (autor Kirill Ivanovitš Golovatševski, 1758, Eesti Kunstimuuseum) võeti näituselt ajutiselt välja ja tuli asendada samuti Eesti Kunstimuuseumi kogusse kuuluva maaliga „Kaana pulm“ aastast 1597 (foto 4), mis pärineb Marten de Vosi töökojast (Vaino 2019). Antud juhul ilmnes õnnelikul kombel, et asenduseks valitud teos toimib esialgsest isegi paremini (Sundja 2019), kuid see ei pruugi alati nii minna.

Foto 4

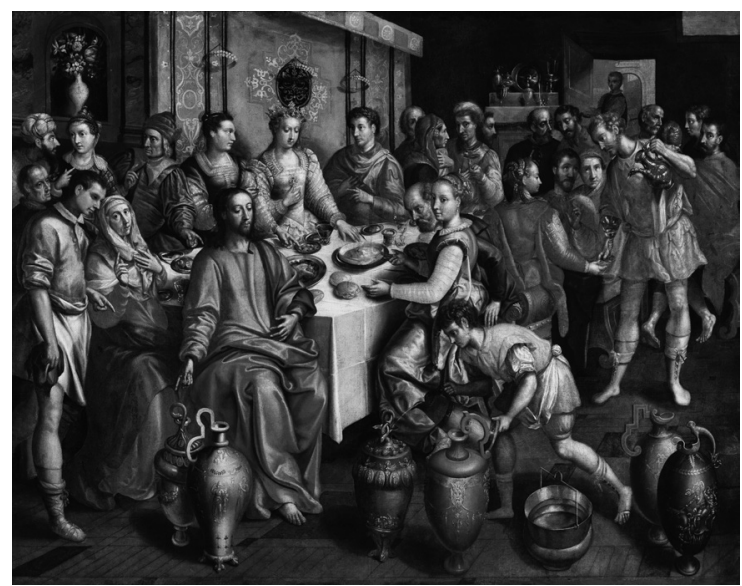

Tartu Kunstimuuseumil ei ole püsiekspositsiooni, mis tähendab, et kõik haridusprogrammid tuleb üles ehitada ajutistele näitustele ja vaid mõne kuu möödudes taas järgmise näituse jaoks ümber teha või pidevalt uusi tunde välja mõelda. See tähendab 
muuseumi haridustöötajale suurt koormust, kuid võimaldab hea planeerimise korral näitusi ja haridusprogramme paindlikumalt ning lühema ajaga vajalike teemade või tegevustega ühitada. Seda võimalust kasutasime osaliselt näituse „Lugusid kuulumisest“ ettevalmistamise käigus, kuna näituse koostamise perioodi poole peal sai selgeks, et sellele on plaanis välja töötada ka koolidele suunatud kiusuennetusprogramm. Valituks osutus just Rootsi kaasaegse kunsti näitus, kuna selle kontseptsiooni keskmes olevateks teemadeks on kaasatus ja tõrjutus, mis haakuvad kiusuennetuses käsitletavate põhimõtetega. Mitmed näitusel osalevad autorid on immigrandi taustaga ja vahendavad oma teostes Rootsi ühiskonda sulandumise raskustega seonduvaid kogemusi. Nende teoste kaudu on võimalik näidata ka kiusamise kui laiema ühiskondliku probleemi aktuaalsust ja seoseid maailmas toimuvaga. Näituse tekstide ja teoste tutvustuste koostamisel oli võimalik kiusuennetuse perspektiivi arvesse võtta ja esile tuua ning teoseid puudutav vajalik info enne avamist programmi koostamiseks tunnijuhtidele edastada. Vaino kogemuse põhjal saavad tunnijuhid tavaliselt info siis, kui näitus on juba avatud, aga tema sõnul on varem infot saada positiivne ja tekitab tunde, et tunnijuhtidega arvestatakse (Vaino 2019). Tulenevalt sellisest kureerimisprotsessist on Tartu Kunstimuuseumi tunnis kasutatavad tööd küll Kadrioru kunstimuuseumi teostega võrreldes otsesemalt kiusuennetuse teemadega seotud, kuid seos oleks kindlasti veel tugevam, kui tunni sisu oleks saanud arvesse võtta juba näitusele teoste valimise faasis, mis sel korral ei olnud võimalik, kuna tööde valiku ajal ei olnud veel muuseumitunni ideed ega sisu. Edaspidi valmivate näituste puhul on aga see võimalus olemas.

Tunnid on näidanud, et kuraatorite, näituste kujundajate ja haridustöötajate koostöö oleks oluline ka ruumilahenduste planeerimisel, kuna suure grupiga ühe teose juures viibimine eeldab vajaliku ruumi olemasolu, millest jääb teatud teoste juures väheks nii Kadriorus kui Tartus. Abiks oleks ka segavate helitaustade minimeerimine, mis on ennekõike probleem Tartu näituse videotööde tõttu („Kunstiga kiusamise vastu“ tunni vaatluste andmed, VM 2019, Tartu). Kõigi selliste aspektide kooskõlastamine on väga keeruline ja ei pruugi olla alati võimalik, kuid selles küsimuses saaksid mõlemad muuseumid midagi ära teha, kui kuraatorite ja haridustöötajate suhtlust alustada juba näituste planeerimise varasemas faasis. Selleks on aga vaja nii kuraatorite avatust info ja protsesside jagamisel kui ka haridustöötajate aktiivsust probleemi sõnastamisel ja lahenduste väljapakkumisel. Sageli jääb siinkohal puudu pigem muuseumitöötajate ajast, energiast ja osaliselt ka teadlikkusest, mitte tahtest koostööd teha. 
Kuigi näitust „Lugusid kuulumisest“ püüti teadlikult kiusuennetusprogrammiga sobitada, ei saa olla kindel, et õpilastel on Tartu Kunstimuuseumi teoste kaudu palju lihtsam teemat hoomata. Seda seepärast, et tegemist on kaasaegse kunsti teostega, mille tõlgendamine võib olla pisut keerulisem kui ajalooliste ja visuaalselt jutustavamate teoste puhul, mida eksponeeritakse Kadrioru kunstimuuseumis. Ka mõne õpetaja tagasisidest on põgusalt läbi käinud, et lastel on keeruline kaasaegset kontseptuaalset kunsti mõista, kuigi tunnijuhi selgitused on abiks (õpetajate tagasisideküsitluse vastused 2019). On mõistetav, et Kadrioru püsiekspositsiooni külastamine võib tunduda õpetajatele turvalisem valik, kui viia esimese kuni neljanda klassi lapsed kiusuennetustunniks kaasaegse kunsti näitusele, kus on väljas harjumatud ja sageli ka vastuoluliselt mõjuvad teosed. Teisalt on vaatlused näidanud, et lapsed suudavad tunnijuhi küsimuste toel väga hästi ka tänapäevaseid teoseid analüüsida ning rakendavad oma kujutlusvõimet seejuures väga loominguliselt ja leidlikult. Eriti hästi tuleb see esile Sahar Al-Khateebi katkistest mööbliesemetest ehitatud installatsiooni „Nimeta“ (foto 5) puhul, mis on tekitanud õpilastes aktiivset huvi ja rohkelt pakkumisi, millega võiks tegu olla (näiteks on pakutud remonti, segamini tuba, kosmoselaeva,

Foto 5

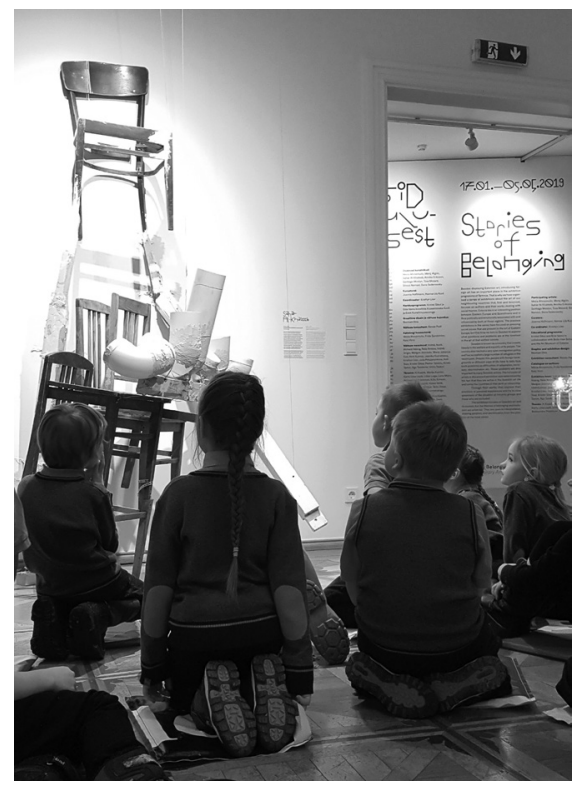

laborit jne). Samuti suudavad lapsed lähemal vaatlusel teose ideed hästi tabada - korduvalt on iseseisvalt esile toodud nii asjade taaskasutuse aspekti kui ka paralleeli kõrvale heidetud mööbliesemete ja välja jäetud inimeste vahel („Kunstiga kiusamise vastu“ tunni vaatluste andmed, 
VM 2019, Tartu). Samuti näib, et laste kogemustega haakuv omavahelise suhtluse teema on toeks, et ka kaasaegse kunstiga julgemalt tutvust teha, ning teoste formaadid ja kontseptsioonid ei ole osutunud teemade käsitlemisel märgatavaks takistuseks. Seega ei tohiks muuseumid ise peljata lastele suunatud tundide koostamist kaasaegse kunsti näitustele, vaid peaksid pigem keskenduma sellele, et võimalikult efektiivselt õpetajate kõhklusi maandada, andes neile piisavalt eelinfot ja tuues selgemalt välja tänapäevases kunstis peituvaid võimalusi õpilaste loovust ja analüüsivõimet arendada.

\section{Kokkuvõte}

Esmapilgul võib kiusuennetusega kunstimuuseumides tegelemine tunduda ootamatu arengusuunana, kuid nagu arutelu näitab, on selleks mitmeid põhjusi nii muuseumide, üldhariduskoolide kui ka Kiusamisvaba Kooli vaatepunktist. Kuna kooliõpilased on muuseumidele oluliseks sihtrühmaks ning kiusuennetusega on hakatud koolides viimastel aastatel aktiivsemalt ja süsteemsemalt tegelema, on nii Kadrioru kunstimuuseumi kui ka Tartu Kunstimuuseumi töötajad pidanud oluliseks sellesse panustada, luues vaheldust võimaldava kiusuennetustunni väljaspool koolimaja. Avanes võimalus pakkuda koolidele muuseumitundi, mis ühendab kahte vajalikku teemat: kiusuennetust ja kunsti vahendamist, samuti koolitada tunnijuhte, kuidas oskuslikult kiusuolukordadesse sekkuda, ja rakendada museoloogiavaldkonna aktuaalseid teoreetilisi suundumusi praktikas. Seega on tegemist ühe näitega laiemast muuseumiuuenduse protsessist, mille käigus püüavad mäluasutused jõuda oma kogukonnale lähemale ja seada nende vajadused oma tegevuse planeerimisel kesksele kohale. Kiusamisvaba Kooli jaoks on täiendav eelis see, et tunni kaudu saab KiVa programmi tutvustada ka nendele koolidele, kes pole veel sellega liitunud. Sellegipoolest on tegemist alles esmase algatusega, mida tuleks kindlasti edasi arendada, et leida ühekordsest külastusest jätkusuutlikumaid koostööformaate, mille mõju õpilastele oleks pikaajalisem. Samuti tuleks kasuks, kui kiusuennetusega tegelevad muuseumid seoksid selle tugevamalt oma laiemate strateegiliste suundumustega, kuna vastasel juhul võib see jääda vaid põgusaks katsetuseks, millele ei järgne edasist arendustööd ega jätkutegevusi. Abi oleks ka sellest, kui lisanduks täiendavaid rahastusallikaid muuseumide sotsiaalse suunitlusega projektide toetamiseks.

Muuseumitund „Kunstiga kiusamise vastu“ on oma ülesehituselt ja taotlustelt küllaltki intensiivne, ühendades 90 minuti sees kunstiteoste vahendamise ja kiusuennetuseks vajalike põhimõtete 
edasiandmise ning kasutades selleks nii arutelusid, mänge kui ka käelist tegevust. Ometi näib selline lahendus ennast suuremalt jaolt õigustavat, kuna igal tunni elemendil on oma konkreetne ülesanne ja need toetavad üksteist. Kunstiteoste kaudu kiusamisega seotud teemade käsitlemine võimaldab lastel oma kogemuste pinnalt teoseid analüüsida ning samas läbi kunstniku vaatepunkti tuttavatele olukordadele uuest küljest läheneda. Koostöömängud aitavad arutelus tehtud järeldusi praktikas katsetada ning leitud põhimõtetele illustratsioonide joonistamine ja lepingu koostamine võimaldab uusi teadmisi kinnistada. Samuti annab lepingu sõlmimine koos piduliku allkirjastamisega kokkuleppele suurema kaalu. Kuigi tunni konkreetset mõju osalejatele ei ole veel olnud võimalik detailselt uurida, siis senised andmed annavad põhjust arvata, et tund võimaldab kunstiteadmisi ja sotsiaalseid oskusi ning hoiakuid samaaegselt edasi anda. Võrreldes kunstimuuseumide tavapäraste haridusprogrammidega on siiski rohkem rõhku pandud väärtuste kujundamisele. Tunni efektiivsuse tõstmiseks oleks kasulik suurendada muuseumitöötajate ja õpetajate omavahelist suhtlust enne ja pärast tundi, et panna paika vastastikused ootused ja vahetada infot nii konkreetse klassi vajaduste kui ka tunni eripärade ning võimalike jätkutegevuste kohta.

Võrreldes tunni sidumist Kadrioru kunstimuuseumi ja Tartu Kunstimuuseumi näitustega, ilmnes, et see sobib ühitamiseks nii püsiekspositsiooni kui ka ajutise näitusega, aga kui esimese puhul on eeliseks see, et tundi on võimalik (teatud mööndustega) kasutada muutusteta pikema aja jooksul, siis teise puhul on eeliseks võimalus näitust ja tunni sisu paindlikumalt kooskõlla viia. Siiski näitab senine praktika, et kumbagi eelist ei ole veel olnud võimalik täiel määral ära kasutada. Kusjuures abi oleks ka sellest, kui tiheneks kuraatorite ja tunnijuhtide omavaheline suhtlus näituste ruumilahenduste ja helitaustade planeerimisel. Samas ei ole kumbki näitus ega formaat osutunud tunni jaoks sobimatuks. See ilmneb ka tunni läbiviimise võrdlemisel ajalooliste teoste versus tänapäeva kunsti näitusel. Nii kõnealuse kiusuennetusprogrammi kui ka teiste analoogse sotsiaalse suunitlusega muuseumiprogrammide arendamine ja sissetöötamine nõuavad aega. Sellest tulenevalt ei ole nende mõju kohta võimalik väga varases faasis põhjapanevaid järeldusi teha, vaid tuleb piirduda esmaste katsetuste kaardistamise ja analüüsiga, mida pakub ka siinne artikkel. Põhjalikum mõju uurimine on tulevaste uurimuste keskmes. Mõlemad muuseumid otsustasid 2019. aasta sügisel tundidega jätkata. Tartu Kunstimuuseumis kasutatakse selleks esmalt näitust „Pallas 10o. Kunstikool ja kultus“, mille esimene kiusuennetustund toimus kevade lõpus ning õpetajate jätkuva huvi korral on võimalik, et seda kohandatakse ka edaspidi uutele näitustele. Küll aga tähendab tihe

\section{4}


näituste vahetumine, et programmi jätkumiseks Tartus on vaja seda pidevalt kohandada.

Edasise uurimistegevuse vaatepunktist on lisaks kiusuennetusele Eestis ka mitmeid analoogseid algatusi, mida tuleks lähemalt käsitleda. Samuti on kuraatorite ja muuseumide haridustöötajate tulevikuperspektiivis võimalus algatada käimasoleva muuseumiuuenduse kontekstis koostööd veel paljude sihtgruppidega. Piiratud ressursside tingimustes muutub aga aina olulisemaks läbimõeldud prioriteetide seadmine, sidumaks valdkonna arenguid võimalikult efektiivselt kohalike vajadustega ning hoidumaks sotsiaalsete projektide ellukutsumisest pelgalt selleks, et üldise vooluga kaasa minna.

\author{
HANNA-LIIS KONT (MA) on vabakutseline kuraator \\ ja museoloog ning Eesti Kunstiakadeemia \\ kunstikultuuri teaduskonna doktorant. Tema \\ keskseks uurimissuunaks on kunstimuuseumide \\ tänapäevased kureerimispraktikad seoses \\ haavatavate ühiskonnagruppidega. Kuni \\ 2018. aasta detsembrini töötas ta Tartu \\ Kunstimuuseumis näituste osakonna juhatajana, \\ viimastel aastatel on ta kureerinud muuseumile \\ mitmeid eesti ja rahvusvahelise kunsti näitusi.
}

\title{
Allikad
}

Meiliintervjuu Kadrioru Kunstimuuseumi haridusprogrammide kuraatori Loore Sundjaga, aprill 2019 (kirjalikud vastused autori valduses).

Tartu Kunstimuuseumi programmis „Kunstiga kiusamise vastu“ osalenud õpetajate seas tehtud tagasisideküsitluse vastused, 2019 (andmed autori valduses).

$\mathrm{VM}=$ Välitöömaterjal. Intervjuu muuseumitunni „Kunstiga kiusamise vastu“ väljatöötaja Eliis Vainoga 22.03.2019 (lindistus ja üleskirjutus autori valduses).

VM = Välitöömaterjal. Intervjuu Tartu Kunstimuuseumi muuseumipedagoogi Kristel Sibulaga 20.03.2019 (lindistus ja üleskirjutus autori valduses).
VM = Välitöömaterjal. Intervjuu SA Kiusamisvaba Kooli tegevjuhi Triin Toomesaarega 01.04.2019 (lindistus ja üleskirjutus autori valduses).

VM = Välitöömaterjal. „Kunstiga kiusamise vastu“ tunni vaatluste andmed 2019 Tartus ja Tallinnas (vaatluslehed autori valduses).

VM = Välitöömaterjal. Triin Toomesaare poolt Eesti Kunstimuuseumi ja Tartu Kunstimuuseumi töötajatele o8.01.2019 läbi viidud koolituse märkmed (üleskirjutus autori valduses). 


\section{Kirjandus}

Arseneault, Louise; Bowes, Lucy; Shakoor, Sania. IX 2009. Bullying victimization in youths and mental health problems: 'Much ado about nothing'? - Psychological Medicine 40 (5): 717-729.

Arts Council England kodulehekülg. Arts, culture and wellbeing. https://www.artscouncil. org.uk/how-we-make-impact/arts-culture-and-wellbeing (viimati külastatud 29.03.2019).

Cities of Migration. 23. juuni 2017. Multaqa: Museums Welcome Refugees. https://citiesofmigration.ca/good_idea/multaqa-museums-welcome-refugees/ (viimati külastatud 08.07.2019)

Crystal Bridges Museum of American Art kodulehekülg. 2013. Crystal Bridges Museum of American Art \& University of Arkansas Department of Education Reform Announce Results of a Study on Culturally Enriching School Field Trips. https://crystalbridges.org/blog/ crystal-bridges-museum-of-american-artuniversity-of-arkansas-department-of-education-reform-announce-results-of-a-studyon-culturally-enriching-school-field-trips/ (viimati külastatud 10.04.2019).

Dewdney, Andrew; Dibosa, David; Walsh, Victoria (toim). 2012. Post-Critical Museology: Theory and Practice in the Art Museum. London: Routledge.

Dickstein Thompson, Laura. 2010. Addressing challenging topics: A case study. - Fortney, Kim; Sheppard, Beverly (toim). An Alliance of Spirit: Museum and School Partnerships. Washington DC: AAM Press, 51-56.

Dodd, Jocelyn; Jones, Ceri. Juuni 2014. Mind, Body, Spirit: How Museums Impact Health and Wellbeing. University of Leicester: Research Centre for Museums and Galleries. https:// lra.le.ac.uk/bitstream/2381/3169o/4/MBS\%2O Final\%2oReport.pdf (viimati külastatud 16.04.2019).

Eesti Kultuurkapitali kodulehekülg. Eesti Kultuurkapitali raha jagamise üldkord. https://www. kulka.ee/taotlemine/eesti-kultuurkapitali-raha-jagamise-uldkord-kehtiv-alates-15-04-19 (viimati külastatud 27.04.2019).
Eesti Muinsuskaitseameti kodulehekülg. Muuseumid Eestis. https://www.muinsuskaitseamet. ee/et/kultuuriparand-eestis/muuseumid-eestis (viimati külastatud 24.09.2019).

Eesti Muuseumiühing. detsember 2017. Eesti Muuseumiühingu Arengukava 2018-2022. https://www.muuseum.ee/wp-content/ uploads/2018/01/171220-Eesti-Muuseumiuhing-2018-2022.pdf (viimati külastatud 28.03.2019).

Eesti Pagulasabi. 30.04.2018. Kui palju on Eestis pagulasi? https://www.pagulasabi.ee/blog/ kui-palju-eestis-pagulasi (viimati külastatud 10.07.2019).

Greene, Jay P.; Kisida, Brian; Bowen, Daniel H. Talv 2014. The Educational Value of Field Trips. Education Next 14 (1). https://www.educationnext.org/the-educational-value-of-field-trips/ (viimati külastatud 10.04.2019).

Haridus- ja Teadusministeerium. Kiusamisvaba haridustee kontseptsioon. 2017. https://www. hm.ee/sites/default/files/kiusamisvaba_haridustee_kontseptsioon.pdf (viimati külastatud 28.03.2019).

Johnson, Julie I.; Rassweiler, Janet L. 2010. Connecting museum, school, and community: Collaborations for learning. - Fortney, Kim; Sheppard, Beverly (toim). An Alliance of Spirit: Museum and School Partnerships. Washington, D.C.: AAM Press, $65-72$.

Kadrioru Kunstimuuseumi kodulehekülg. Kirjeldustõlked. https://kadriorumuuseum.ekm.ee/kirjeldustolked1/ (viimati külastatud 10.07.2019).

Kiusamisvaba Kooli kodulehekülg. Iga viies Eesti koolilaps on kiusamise ohver. http://kiusamisvaba.ee/kiusamisest/ (viimati külastatud 06.04.2019).

Kiusamisvaba Kooli kodulehekülg. KiVa programm - mis, kellele ja milleks? http://kiusamisvaba.ee/kiva-programm/ (viimati külastatud 19.03.2019).

KiVa International. http://www.kivaprogram. net/is-kiva-effective (viimati külastatud 01.07.2019). 
Kumu Kunstimuuseumi kodulehekülg. 2018. Taaskohtumised. https://kumu.ekm.ee/syndmus/ taaskohtumised-2/ (viimati külastatud 08.07.2019).

Kumu Kunstimuuseumi kodulehekülg. 2019. Lasteaiale ja põhikooli I astmele. Muuseumitunnid püsinäitusel. https://kumu.ekm.ee/lasteaiale-ja-pohikooli-i-astmele/?fbclid=IwAR1NzAfaaL1pvmJXvlk_jhKp_u-NY5eqPTloX4LECpOliM-wDOGzhLTdkyc (viimati külastatud 10.07.2019).

Marstine, Janet. 2006. New Museum Theory and Practice. Oxford: Blackwell.

MoMA kodulehekülg. Meet Me at MoMA. The MoMA Alzheimer's Project: Making Art Accessible to People with Dementia. https:// www.moma.org/visit/accessibility/meetme/ (viimati külastatud 08.07.2019).

Museums Association. 2018. Measuring Socially Engaged Practice: A Toolkit for Museums. https://www.museumsassociation.org/ download?id=1249262 (viimati külastatud 29.03.2019).

Museum of Tolerance kodulehekülg. Steps to Tolerance. An Effective Bullying Prevention Program. http://www.museumoftolerance.com/ education/youth-programs/programs-for-elementary-schools/steps-to-tolerance.html (viimati külastatud 16.04.2019).

Petkute, Ieva; Gudonytè, Eglè; CIC „,arthur+martha“. 2016. Sing me to Sleep. http://www.menasgerovei.lt/sing-me-to-sleep.html (viimati külastatud 09.07.2019).
Salmivalli, Christina; Poskiparta, Elisa; Tikka, A.; Pöyhönen, Virpi. 2013. Kiusamisvastane programm KiVa. Õpetaja käsiraamat, 1. moodul. Turu: Turu Ülikool.

Scotto, Ashley. 2014. United We Stand: The Possibilities of Museums, Schools, and Anti-Bullying. Seton Hall University Thesis.

Tartu Kunstimuuseumi kodulehekülg. 2018. Tutvumine saviteraapiaga. Töö saviväljal. https:// tartmus.ee/uritus/tutvumine-saviteraapiaga/ (viimati külastatud 10.07.2019).

Thomson, Linda J; Chatterjee, Helen J. 2013. UCL Museum Wellbeing Measures Toolkit. https:// www.ucl.ac.uk/culture/sites/culture/files/ ucl_museum_wellbeing_measures_toolkit_ sept2013.pdf (viimati külastatud 29.04.2019).

van Mensch, Peter. 2004. Museology and Management: Enemies or Friends? Current Tendencies in Theoretical Museology and Museum Management in Europe. http://icom-portugal.org/multimedia/File/V\%20Jornadas/ rwa_publ_pvm_2004_1.pdf (viimati külastatud 06.04.2019).

World Healthcare Congress Europe 2019 kodulehekülg. http://europehealthcare.org/conference-themes/ (viimati külastatud 29.03.2019). 


\section{Summary: Anti-bullying educational
programmes for schools in
Estonian art museums}

Hanna-Liis Kont

With the shift of focus on the part of museums towards a fuller consideration of the audience's needs, a number of museums around the world have begun to contribute more actively and consciously to people's welfare, including their physical and mental health and the inclusion of more vulnerable and marginalised social groups. Several museums in Estonia have joined in these efforts over the past few years. A specific example of such a museum innovation is the work that has been done with bullying prevention. To date, studies have shown that one in five children attending a school in Estonia is a victim of bullying and that bullying can cause anxiety and depression, or in other words, it can significantly affect one's mental health. Although there are several organisations in Estonia dealing with this problem, more active cooperation with museums started only in 2018 when Kadriorg Art Museum and Tartu Art Museum, independently of one another, contacted the Foundation for the Bullying-Free School with the request to develop anti-bullying educational programmes for schools of general education. As a result of the cooperation, two versions of the museum lesson, 'Art Against Bullying', were prepared for both museums.
The article addresses the questions of why the above art museums decided to undertake their bullying prevention initiative and how this concern and art mediation are combined in the structure of educational programmes and to some extent, in that of the exhibitions. There are several reasons for undertaking anti-bullying initiatives in art museums from the perspective of both schools and museums as well as the Foundation for the Bullying-Free School. As school children have become an important target group, museums have sought to adapt their programmes, as effectively as possible, to the needs of schools. Considering that schools likewise have become more proactive and systematic in their approach to bullying, museums have seen this as an opportunity to offer alternative anti-bullying lessons outside the classroom routine. The development of such a lesson has provided an opportunity to simultaneously offer schools a museum lesson which would combine two critical themes-bullying prevention and art mediation-as well as train instructors in how to intervene expertly in bullying situations and apply current theoretical approaches. An added bonus for the foundation is that the museum lesson enables them to introduce 
the Bullying-free School programme to the schools that have not yet joined it and offer further knowledge consolidation activities to the schools that have already enrolled in the programme. However, it is still a young initiative that needs further development in order to find more sustainable collaboration formats which would have a more long-term influence on school children than a single museum visit. It is likewise important that the museums should seek to tie bullying prevention more strongly to their broader strategic orientations, or otherwise they run the risk of it remaining an ephemeral experiment that is not grounded by continuous development or follow-up activities.

Through discussions, cooperative role plays and a craft activity, the museum lesson, 'Art Against Bullying', combines mediation of art works and introduction to anti-bullying principles. Discussion of topics related to bullying through works of art enables children to analyse art works in the light of their own experience and to approach familiar situations from a novel angle provided by the artist's perspective. The co-operative role plays help to test out in practice the conclusions of the discussions. To consolidate the recently gained knowledge children are tasked with drawing pictures and compiling a contract based on the pictures. Although it has not yet been possible to study in detail the impact of the lesson on the participants, an analysis of the existing data suggests that it is possible to impart simultaneously knowledge regarding the essence of art as well as social skills and attitudes. Art and bullying prevention act in partnership, so to speak, where they support each other without either of them becoming marginalised. One possible way of making the lesson more effective, however, would be the tightening of the interaction between the museum staff and teachers outside the lesson time so as to negotiate mutual expectations and exchange information regarding both the needs of a particular class and the specific adjustment of the lesson as well as follow-up activities. When examining the way in which the lesson was anchored to different exhibition environments, it became clear that the lesson could be combined with a variety of art expositions, including permanent displays and temporary exhibitions as well as displays of both historical and contemporary art. Regardless of the exhibition context, however, interaction between the curators and museum educators in the planning of spatial solutions and sound design could be further strengthened in order to deliver a more effective lesson.

For curators and museum educators, the ongoing museum innovation holds the potential for initiating co-operation with many other target groups. However, given the limited resources, it is increasingly more important to choose priorities very carefully in order to align, as effectively as possible, the developments in the field with the local needs. 


\section{Музейные образовательные программы по профилактике травли в художественных музеях Эстонии}

Ханна-Лийс Конт

Вместе с перемещением фокуса деятельности музеев в сторону большего учёта потребностей публики многие музеи мира стали активнее и осознаннее вносить свой вклад в благополучие людей, в т. ч. привлекая к участию уязвимые или оставленные без внимания социальные группы и содействуя укреплению их душевного и физического здоровья. В последние годы в эту работу включились также эстонские музеи. Одним из конкретных примеров описанных новшеств является работа, направленная на предупреждение травли. Исследования показывают, что каждый пятый школьник в Эстонии подвержен травле, и что травля может сопровождаться тревожностью и депрессией, что существенно влияет на душевное здоровье. Данной проблемой в Эстонии занимаются несколько организаций, однако активное сотрудничество с музеями началось лишь в 2018 году, когда Кадриоргский художественный музей и Тартуский художественный музей независимо друг от друга обратились в целевое учреждение «Школа без травли» с предложением разработать для общеобразовательных школ музейные образовательные программы по профилактике травли. Результатом сотрудничества стали два варианта музейных занятий «Искусство против травли».

В статье представлены ответы на вопросы, почему художественные музеи решили заниматься профилактикой травли и каким образом сочетаются предупреждение травли и представление искусства в структуре образовательных программ и отчасти выставок. Для работы по профилактике травли в художественных музеях имеется несколько причин как с точки зрения музеев, так и школ и ЦУ «Школа без травли». Поскольку учащиеся школ являются для музеев очень важной целевой аудиторией, музеи задаются целью по возможности эффективнее приспособить свои программы к потребностям школ. Принимая во внимание то, что в школах стали активнее и более системно заниматься предупреждением травли, музеи увидели возможность внести свой вклад, предлагая разнообразные альтернативные 
внешкольные занятия по профилактике травли. У музеев появилась возможность предложить школам занятия, объединяющие в себе две важные темы профилактику травли и искусство, обучить ведущих уроков со знанием дела вмешиваться в ситуации травли и применять актуальные теоретические знания на практике. Дополнительным преимуществом для «Школы без травли» видится то, что посредством этих занятий «Школа» может представить свою программу учебным заведениям, ещё не присоединившимся к ней, а уже примкнувшим школам предложить занятия для закрепления знаний. Этот проект лишь первичное начинание, которое следует развивать, чтобы найти для школ и музеев более жизнеспособные формы сотрудничества с более длительным влиянием на школьников, чем одноразовые посещения музеев. Важно также, чтобы музеи тесней связали профилактику травли со своим стратегическим развитием, иначе это станет лишь беглым опытом, и никакой последовательной разработки и продолжения не последует.

На музейных занятиях «Искусство против травли» представление произведений искусства и передача необходимых для профилактики травли принципов происходит через обсуждения, игры, ручную работу. Рассмотрение связанных с травлей тем посредством произведений искусства даёт детям возможность проанализировать произведения, исходя из своего опыта, и в то же время благодаря видению художника по-новому увидеть уже знакомые ситуации. Совместные игры после дискуссий позволяют проиграть и испытать на практике выводы, сделанные на обсуждении. Передача выявленных принципов в рисунках и составление договора из рисунков позволяет закрепить новые знания. Несмотря на то, что влияние занятий на принимавших в них участие школьников детально ещё не изучено, анализ имеющихся данных показывает, что занятия позволяют одновременно передавать суть искусства, а также социальные навыки и взгляды. При этом искусство и профилактика травли действуют как дополняющие друг друга составляющие, и ни одна из них не становится маргинальной. Однако, для увеличения эффективности занятий было бы полезно сделать более интенсивным общение работников музея и учителей вне рамок занятий, чтобы выяснить взаимные ожидания и обменяться информацией как о потребностях конкретного класса, так и об особенностях занятий и возможной последующей работе. При рассмотрении связанности занятий с различной выставочной средой выясняется, что они сочетаются с довольно разными художественными выставками - как с постоянными, так и временными экспозициями, как с историческим, так и современным искусством. Независимо от типа выставок будет полезно, если кураторы и ведущие 
занятий станут тесней общаться при планировании пространства и звукового фона выставки, чтобы эффективнее проводить занятия.

В будущем в контексте проводимого обновления музея можно инициировать сотрудничество со многими другими целевыми группами. Однако, в условиях ограниченности ресурсов всё более важным становится взвешенная расстановка приоритетов, чтобы по возможности эффективно связать развитие отрасли с потребностями на местах. 